\begin{tabular}{ll}
\hline \hline MINING AND METALLURGY INSTITUTE BOR & ISSN: 2334-8836 (Štampano izdanje) \\
UDK: 622 & ISSN: 2406-1395 (Online) \\
\hline \hline
\end{tabular}

Gordana Milentijević, Blagoje Nedeljković, Jelena Đokić*

\title{
IMPLEMENTATION THE ENVIRONMENTAL PROTECTION SYSTEM IN THE TERRITORY OF THE KOSOVSKA MITROVICA AND ZVEČAN MUNICIPALITIES**
}

\begin{abstract}
The aim of the paper is to determine the possibility of using the system of environmental protection of $R S$ in the territory of Zvecan and Kosovska Mitrovica municipalities. Further, the aim is to show the results on the environmental situation in the municipalities of Zvecan and Kosovska Mitrovica in the period from 2006-2013. Conduct the analysis predicted by the laws and regulations made in the period from 2006-2013.

For the purposes of this paper information were collected in the services of competent authorities dealing with monitoring the implementation of environmental protection systems and environmental monitoring in the municipality of Zvecan and Kosovska Mitrovica. In addition, the analyzes were performed of industrial landfills using two following methods: atomic absorption spectroscopy and scanning electronic microscopy.

In the municipalities of Zvecan and North Mitrovica the environmental protection laws are implemented but with smaller or larger deviations. For the municipality of Kosovska Mitrovica LEAP was developed, while the Development Plan (2006-2009) and Development Strategy (2013-2017) are made for both municipalities.
\end{abstract}

Keywords: environment, air quality, water quality, soil quality, industrial landfills, environmental protection systems

\section{INTRODUCTION}

Environmental protection system in the RS, according to the Law on Environmental Protection of RS (Official Gazette No.s 135/2004, 36/2009, 36/2009-St. Law 72/2009 - St. Law and 43/2011-US decision) is constituted by the measures, conditions and instruments for:

1. Sustainable management, conservation of natural balance, integrity, diversity and quality of natural values and conditions for survival of all living beings,

2. Prevention, control, decrease and rehabilitation of all forms of environmental pollution.
These measures can only conditionally be classified into:

1. Administrative measures of protection

2. Technical protection measures

3. Organizational protection measures

4. Economic measures

5. Education and informing

From the above mentioned the aim of the paper is derived, reflected in the establishment of implementation the environmental protection system in RS municipalities of Zvecan and Kosovska Mitrovica. In this regard, this paper presents the results of the state of the environment and of

\footnotetext{
* University of Pristina, temporarilyheadquarters in Kosovska Mitrovica, Faculty of Engineering, Kneza Miloša 7, e-mail: blagojenedeljkovic@yahoo.com

** This realized study was supported by the Ministry of Education, Science and Technological Development of the Republic of Serbia (Project No. III43007, Project No. TR.33045)
} 
the analysis provided by laws and bylaws realized in the period of 2006-2013 in the municipalities of Zvecan and Kosovska Mitrovica.

The period of economic development from 1918-1941, was characterized by the renewal of mining by English-Serbian company "Trepca Mines Limited" by which Zvečan and Kosovska Mitrovica have become recognizable in the world.

In this area lead and zinc ore mining, lead and zinc concentrations, non-ferrous metallurgy, chemical industry and light industry were developed, which took place within RMHK Trepca. From the power plant of zinc metallurgy there came to emissions of zinc, cadmium, phosphorus and sulfur in the air, water and land, and in the lead metallurgy plants there came to emissions of lead, arsenic, antimony, copper and sulfur. The transmission through the environment of the specified pollutants caused a serious pollution by heavy metals in a wide area that included the valleys of the rivers Ibar and Sitnica. The ore mining and concentration created a large amount of tailings that accumulated over time and grew into major landfills located near settlements and the alluvial sediments of Ibar. It can be concluded that the biggest polluter in the municipalities of Zvecan and Kosovska Mitrovica has precisely been RMHK Trepca, which is still reflected in all aspects of the environment.

This defined the issues presented in this paper, namely:

1. possibilities of implementation the environmental protection system, and

2. environmental situation in the territory of the municipalities of Zvecan and Kosovska Mitrovica.

\section{EXPERIMENT}

For the purpose of this paper the information were collected in the municipalities of Kosovska Mitrovica and Zvecan in the agencies dealing with the environmental monitoring.
In order to determine the effects of pollutants from the air, water and soil to the environment analyzes of their quality were performed.

Further, for determination the impact of tailings on the environment, before and after solidification, characterization of the samples was performed using chemical, physical and mineralogical tests. Dusting factor was determined laboratorial [1].

\subsection{Air Quality Control}

Testing the air pollution includes (The Center for Research and Development, hereinafter CRD in RMHK Trepca):

1. Testing of sedimentary materials and lead by the meters and targeted dust meters from atmospheric deposits and precipitation.

2. Control of $\mathrm{SO}_{2}$ gas in the air by IMPINGER appliance

3. Control of lead in the air using a high-throughput STAPLEX pump in the operating and urban environment

The tests of air pollution includes 24hour measurements of basic pollutants $\left(\mathrm{SO}_{2}, \mathrm{NO}_{\mathrm{X}}\right.$, and soot) and monthly measurements of sedimentary materials, including testing of sedimentary matter and lead in atmospheric precipitation and sludge, $\mathrm{SO}_{2}$ gas control in the air and control of lead in the air (PHI Kosovo Mitrovica).

\subsection{Water quality control}

The tests include all water tests related to the quality of drinking water and determination of the concentration of organic pollutants and heavy metals in the river Ibar.

For the determination of metals (cations) in liquid samples, the absorption atomic spectroscopy and spectrophotometry are usually applied. When analyzing water samples of the river Ibar, the AAS method was used.

\subsection{Soil quality control}

Soil quality control was carried out within RMHK Trepca and surrounding area where the quality of arable land was tested. 
The analysis of samples of the surroundding land was performed using the XRF method X-ray Fluorescence (X-ray fluorescence)

\subsection{Materials characterization}

Chemical composition of the samples was determined using the $\mathrm{x}$-ray fluorescence (ARL86480) device. The tests by scanning electronic microscopy were performed at the electron microscope Philips XI-300 with EDX- EDAX, with a resolution of $1 \mathrm{~nm}$ (30 $\mathrm{kV}$ ) and $5 \mathrm{~nm}(1 \mathrm{kV})$, voltage of $0.2-30 \mathrm{kV}$, magnification of 500,000 times and detectors for secondary and feedback electrons. Mineralogical studies were performed using the diffractometer analysis (XRD). The samples were analyzed at the Philips PW 1710 diffractometer under the following conditions: radiation from copper anticathode with $\mathrm{CuK}=1.54178$ _I graphite monochromator of operating voltage $U=40 \mathrm{kV}$, current strength $I=30 \mathrm{~mA}$. The samples were tested in the range of 2_4-90 (with a step of $0.02^{\circ}$ and $0.8 \mathrm{~s}$ ). Particle size distribution is determined by the BSF cyclosizer [2].

\section{RESULTS AND DISCUSSION}

2.1 Administrative measures in the field of environment in the territory of Zvecan and Kosovska Mitrovica municipalities

In the territory of Zvecan and Kosovska Mitrovica municipalities, the following laws in the field of environmental protection are implemented:

1. The Law on Environmental Protection (Off. Gazette of RS, No. 135/04)

2. Air Protection Act (Off. Gazette of RS, No. 36/09),

3. Water Act (Off. Gazette of RS, No. 30/10),

4. Waste Management Act (Off. Gazette No. 36/09)

Other laws in the field of environmental protection are implemented with minor difficulties or are not implemented.
From strategic documents Local economic development strategies from 20142016 are made. These documents on one hand represent the conditions promoting economic activities and living conditions of area, and on the other hand, the desire of local governments, institutions, agencies, businesses and associations to encourage the development of their communities and contribute to their development by the active participation. The following priority fields are defined:

1. Strengthening the capacity of institutions and human resources for local economic development

2. Sustainable use of natural resources and the environmental protection

3. Attracting the investment and development of small and medium-sized enterprises

4. Agriculture and Rural Development

5. Development of Tourism.

The LEAP Plan was made of plan documents for the municipality of Kosovska Mitrovica. The document is a prerequisite for further sustainable development of the town, whose implementation improves the state of the environment and human health.

The LEAP describes the main problem in the field of environment:

1. Large concentrations of mining, metallurgy and chemical industry production in a small space

2. Proximity of industrial zones in relation to inhabited areas

3. Industrial plants of RMHK Trepca are located in the direction of dominant winds in relation to inhabited areas

4. The constant risk of possible chemical accidents when production facilities of RMHK Trepča are in the production function

5. Failure to comply with the legislation in the field of environmental protection

6. The negative impact of NATO bombing in 1999 on the environment 


\subsection{Organizational measures in the field of environment in the territory of Zvecan and Kosovska Mitrovica municipalities}

The Municipalities of Kosovska Mitrovica and Zvecan do not have in the structure the Department of Environmental Protection. The greatest polluter of the environment in these municipalities is RMHK Trepca. In Zvecan there is the Lead metallurgy with the smelter and refinery, the factory for processing Accum-waste and power plant, etc. In these facilities from lead concentrate beside crude and refined lead also produced are lead alloys of different types, silver and gold. After 1999 RMHK Trepca stops working. Now the greatest danger to the environment is made by the industrial landfills formed from waste which originated from RMHK plants.

In the municipality of Kosovska Mitrovica there is the Faculty of Engineering in which staff are trained in the field of environmental protection, within the study program IEP and WS. In the Zvecan municipality, HTS is located with the course in environmental protection.

In the municipality of Kosovska Mitrovica is the seat of NGO EKOSS (Ecology as the salvation for all of us), established in 2002 in order to:

1. Environmental protection

2. Recycling of waste materials

3. Raising public awareness (workshops, seminars, discussions).

\subsubsection{Air quality}

Air quality monitoring is conducted according to the law on air protection published in (Official Gazette RS, No. 36/2009, 15.05.2009). The law provides the air quality management, as well as a method of control and enforcement to protect and improve air quality.

The main sources of air pollution in Kosovska Mitrovica and Zvecan are the products of fuel combustion in households, power stations, individual boilers, then traffic, construction activity, improper storage of raw materials, improper disposal of industrial waste, garbage dump, the level of public hygiene and other.

\subsubsection{Emission of pollutants}

In the area of Kosovska Mitrovica, the measurements of pollutants under the Regulation on emission limit values, methods and intervals for measuring and recording of data on measurements are not taken. The emission of pollutants is processed only by analyzing the emissions of $\mathrm{SO}_{2}, \mathrm{CO}$ and $\mathrm{NO}_{\mathrm{x}}$ from the Power plant based on the quality of fuel oil and its consumption.

\subsubsection{Emission of pollutants}

The average monthly and annual concentration value of $\mathrm{SO}_{2}, \mathrm{NOx}$ and soot is obtained on the basis of daily measurements. 365 measurements are performed annually. In addition to the concentration of $\mathrm{SO}_{2}, \mathrm{NOx}$ and soot also determined are the quantities of toxic metals from each sample of sedimentary matters-of lead, cadmium, nickel, zinc and hexavalent chromium.

From the annual edition of PHI Kosovska Mitrovica, we analyzed the state of air pollution in 2006, 2007 and 2008, when there was no exceeding of MPC immision of $\mathrm{SO}_{2}, \mathrm{NO}_{\mathrm{X}}$, except for soot. Average monthly and annual mean concentrations of sediments do not exceed MRL for 2006, 2007 and 2008, with the exception of April when the measured values were $632.56 \mathrm{mg} / \mathrm{m}^{2}$ (Measuring point Power Supply) and 490.74 $\mathrm{mg} / \mathrm{m}^{2}$ (kindergarten) [6].

From the results taken from annual reports CRD RMHK Trepca for 2008 it can be concluded that the average annual concentration of settling matters under immission limit values (LIV-300-450 mg/m $/ \mathrm{m}^{2} /$ day). It 
may also be noted that the highest annual average concentration of lead was recorded at measuring point Rudare-gater of 400.06 $\mu \mathrm{g} / \mathrm{m} /$ day (Figure 1) as the result of activities in the former plant of tile brick factory in Žitkovac (drying slag and lead melting) as well as of heavy rainfall and strong winds blowing [7].

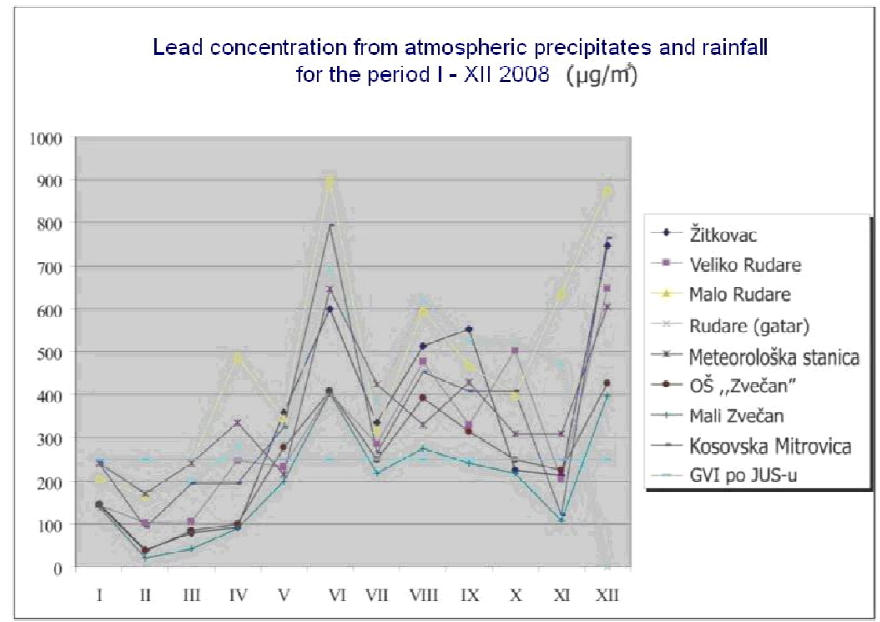

Figure 1 Graphical view of lead concentration from atmospheric precipitation and rainfalls for the period January-December 2008. [7]

\subsubsection{Water quality}

Water quality is carried out according to the Water Act (Official Gazette of RS, No.30/10). All the tests related to the quality of rainwater and waste water discharged to recipients, are performed by PHI in accordance with legal regulations, primarily the Law on Water (Official Gazette of RS, No.46/91, 53/93, 48/94, 54/96), Regulations on Hazardous substances in Water (Official Gazette of RS, no. 31/82), Regulations for testing waste water quality (Official Gazette of RS, no. 47/83), the Regulation on watercourses categorization (Official Gazette of RS, no. 5/68), the Regulation on water Classification (Official Gazette of RS, No. 6/78) and relevant decisions of the Municipal Assembly.

CRD performs testing of water which includes determination of heavy metals in the Ibar.

\subsubsection{Quality of drinking water}

In the period from 2006-2013 PHI annually examined the chemical and bacte- riological quality of drinking water in the number of samples annually ranging from 369-1018 samples in the municipalities of Kosovska Mitrovica and Zvecan. Of this number, the values of chemically unsafe samples of drinking water range from $2.56 \%-5.4 \%$ (Kosovska Mitrovica) and from $4.16 \%-3.15 \%$ (Zvecan); the mean value of bacteriological defective samples are in the range of $9.58 \%-11.6 \%$ (Kosovska Mitrovica) and approximately $10.58 \%-14.9 \%$ (Zvecan) [6].

\subsubsection{The results of heavy metals presence analysis in the river Ibar}

CRD determines the concentration of heavy metals $(\mathrm{Cu}(\mathrm{mg} / \mathrm{l}), \mathrm{Fe}(\mathrm{mg} / \mathrm{l}), \mathrm{Pb}$ $(\mathrm{mg} / \mathrm{l}), \mathrm{Cd}(\mathrm{mg} / \mathrm{l})$ and $\mathrm{Zn}(\mathrm{mg} / \mathrm{l}))$ and basic parameters of water quality indicators: $\mathrm{pH}$, total particulate matter, dissolved solids, insoluble substances, $\mathrm{SO}_{4}$ and $\mathrm{Ca}$ in the Ibar River, once a month. Measuring points of water sampling are also designed 
to reflect the true state of the water quality of the river Ibar in the municipalities of Kosovska Mitrovica and Zvečan [3].

Major pollutants in the municipalities of Kosovska Mitrovica and Zvecan are concentrated mainly in the catchment's area of the river Ibar, next to the river bed or on the alluvial plain. Some basic characteristics of major pollutants with the spillage are given in Table 1 [3].

Table 1 Characteristics the major pollutants in the municipalities of Kosovska Mitrovica and Zvečan

\begin{tabular}{|c|c|c|c|c|}
\hline $\begin{array}{c}\text { Ordinal } \\
\text { number }\end{array}$ & Name of pollutant & $\begin{array}{c}\text { Characteristics of } \\
\text { pollutants }\end{array}$ & Note & $\begin{array}{c}\text { Spillage } \\
\text { point }\end{array}$ \\
\hline 1. & $\begin{array}{c}\text { Flotation dump } \\
\text { "Žarkov potok" }\end{array}$ & $\begin{array}{c}\text { Complex chemical } \\
\text { pollution }\end{array}$ & Periodical pollution & $\begin{array}{c}\text { Žarkov } \\
\text { stream }\end{array}$ \\
\hline 2. & $\begin{array}{c}\text { Landfill } \\
\text { "Gornje polje" }\end{array}$ & $\begin{array}{c}\text { Complex chemical } \\
\text { pollution }\end{array}$ & Constant pollution & River Ibar \\
\hline 3. & Pb metallurgy & $\begin{array}{c}\text { Heavy metals pollu- } \\
\text { tions }\end{array}$ & $\begin{array}{c}\text { Plant outside the } \\
\text { production }\end{array}$ & River Ibar \\
\hline 4. & $\begin{array}{c}\text { Landfill } \\
\text { "Žitkovac" }\end{array}$ & $\begin{array}{c}\text { Complex chemical } \\
\text { pollution }\end{array}$ & Constant pollution & River Ibar \\
\hline
\end{tabular}

Review of the annual reports RDC in a given period of analysis of heavy metals concentrations and basic parameters indicators of water quality in the river Ibar, in the municipalities of Kosovska Mitrovica and Zvecan, we came to the conclusion that they, to a certain number, correspond to the values given in the Law on Waters
Off Gaz. RS, No.30/10. In the diagram in Figure 2, the measuring point Grabovac is given (measuring point reflects the water quality of the river Ibar at the exit from the territory of the municipality of Kosovska Mitrovica and Zvečan) where it noted are the increased contents of heavy metals $\mathrm{Pb}, \mathrm{Cu}$ and $\mathrm{Fe}$ [7].

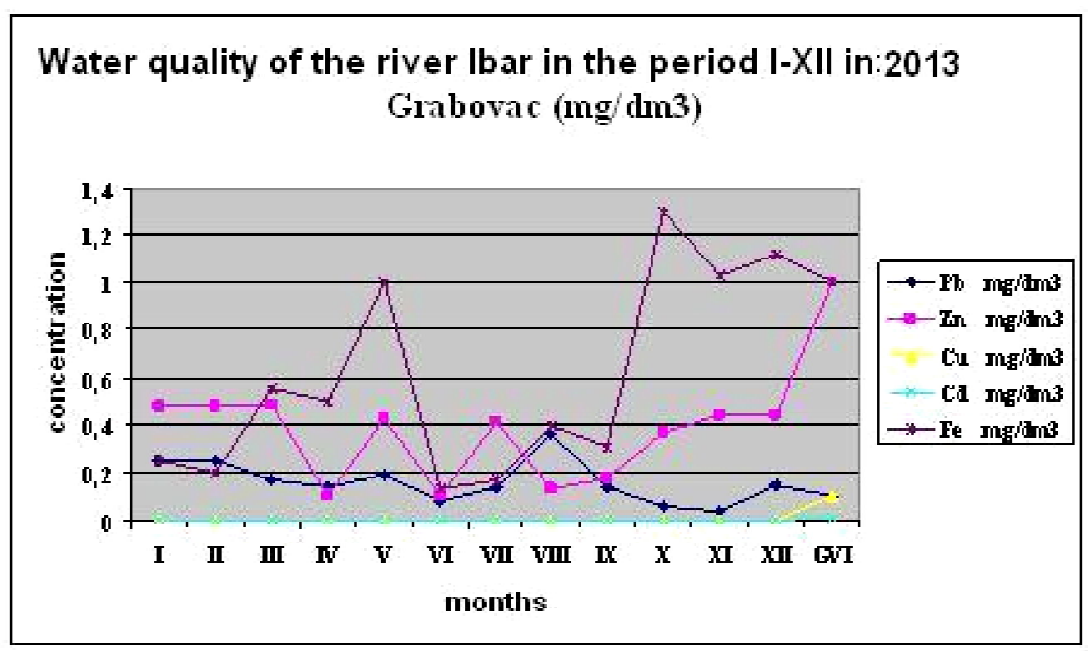

Figure 2 Graph presentation of heavy metals concentration (CRD, 2013) 


\subsubsection{Organic pollutants in the river Ibar in the territory of Kosovska Mitro- vica and Zvecan municipalities}

A great risk of contamination with organic substances represent the thermal power plants Kosovo A and Kosovo B in Obilic. Due to coal combustion there is always the danger that the phenol concentration in recipients is above the MRL, which damages ecosystems. Also, through drinking water and food human population is endangered. Having reviewed the annual reports of PHI Kosovska Mitrovica an extreme situation is given when the analysis showed the presence of phenol in the water of the river Ibar.

Table 2 shows the concentration of volatile phenols in the first six months of
2004 A total of 48 samples was tested by standard method with respect to procedures for sample preservation, distillation, extraction, causing color change and absorbance measurements. This method does not provide the right information about the actual amount of phenolic compounds in water, since it is known that the phenols pollutants, Kosovo power plant and surface coal mines, in their wastewater contain not only volatile but also non-volatile phenolic compounds [4]. Table 2 shows the concentration of volatile phenols in the first six months of 2004.

Table 2 Table of minimum, maximum and common values of the concentration of volatile phenols in water of the river Ibar ( $\mu \mathrm{g} / \mathrm{l})$, in the first six months of 2004 (data from PHI Kosovska Mitrovica, 2004)

\begin{tabular}{|l|c|}
\hline The highest value & $188 \mu \mathrm{g} / \mathrm{l}$ \\
\hline The lowest value & $1.7 \mu \mathrm{g} / \mathrm{l}$ \\
\hline The highest value for a rainy period & $188 \mu \mathrm{g} / \mathrm{l}$ \\
\hline The lowest value for a rainy period & $14.9 \mu \mathrm{g} / \mathrm{l}$ \\
\hline The mean value for a rainy period & $38.6 \mu \mathrm{g} / \mathrm{l}$ \\
\hline The mean value for a dry period & $7.5 \mu \mathrm{g} / \mathrm{l}$ \\
\hline The most common value for a rainy period & $22-58 \mu \mathrm{g} / \mathrm{l}$ \\
\hline The most common value for a dry period & $3.7-12.6 \mu \mathrm{g} / \mathrm{l}$ \\
\hline
\end{tabular}

\subsubsection{Soil Quality}

Measuring the concentrations of heavy metals in the soil is performed by PHI in accordance with the rules on permitted amounts of hazardous and harmful substances in soil and water for irrigation and methods of their testing (Official Gazette of RS, no. 23/94).

The consequences of more than 80 years of RMHK Trepča operation even today affect land degradation because there is a large amount of pollutants that were liberated in the processes of production of lead, zinc and chemical industries, which were deposited in

tailings ponds or are scattered in the environment. Numerous studies have shown that the land within a radius of $10 \mathrm{~km}$ away from the stacks of the lead smelter in Zvecan is seriously polluted mainly by heavy metals such as lead, arsenic, mercury, zinc, copper, nickel and chromium. In this paper, the example of the concentration of arsenic and mercury in measuring points arranged concentrically around the circle of RMHK Trepca in the municipalities of Zvecan and Kosovska Mitrovica (Figure 3). 
From the graph we can see that the concentration of arsenic exceeded the MAC for the permitted amounts of hazardous and harmful substances, which amounts to 2 $\mathrm{mg} / \mathrm{kg}$ of the soil, while mercury was not singled out. The concentrations of other herein mentioned heavy metals in the soil in most cases exceeded the MRL, which resulted also in their excess concentration in plants used for human consumption [5].

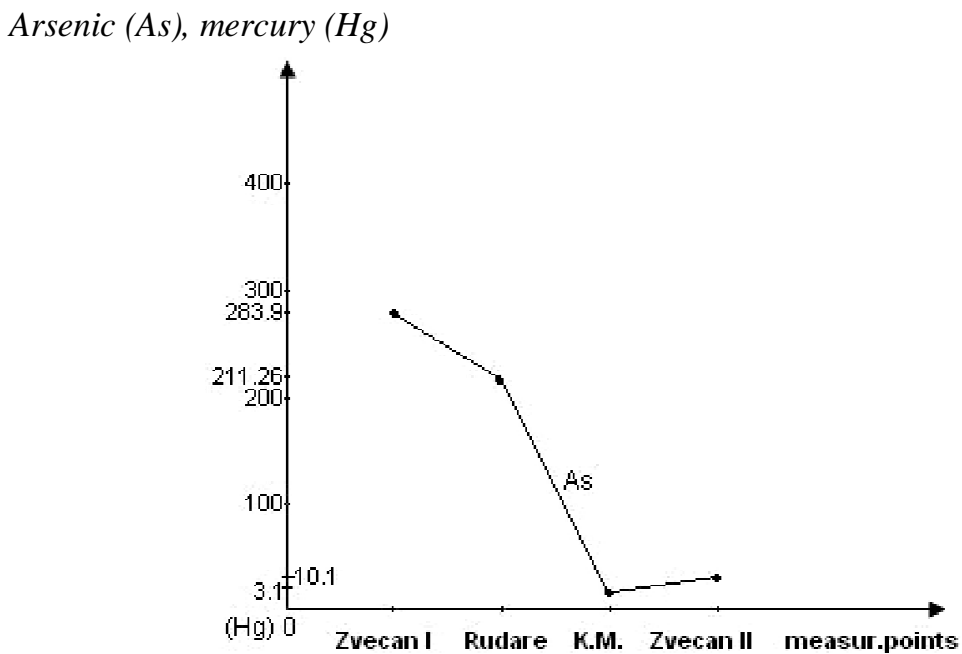

Figure 3 Graphic concentration of arsenic and mercury according to the measuring points [5]

\subsubsection{Waste Management}

Waste collection is done in accordance with the Law on Waste Management (Off. Gaz. RS, no. 36/09 and 88/10), which regulates: types and classification of waste, waste management planning, waste management operators, waste management organization, management of specific waste streams, conditions and procedures for issuing permits, transboundary movement of waste, the waste reporting and database, waste management financing, monitoring, and other issues of importance for waste management.

Inadequate waste management is one of the biggest environmental problems in the municipalities of Kosovska Mitrovica and Zvecan.

\subsubsection{Municipal waste}

Collection, removal and treatment of municipal waste is the responsibility of the PUC from Kosovska Mitrovica and Zvecan. In 2002, in the territory of Zvečan municipality landfill Balaban was constructed, which was supposed to be of a regional character for the municipalities of Kosovska Mitrovica, Zvecan, Zubin Potok and Leposavic. However, due to the path length and unprofitability the municipality Zubin Potok does not use the landfill.

Construction of the landfill, which has been used for the last 10 years, meets the all requirements for disposal of municipal waste. Sanitary waste is not separated because there is no special landfill for such waste but is collected as municipal waste, and this also stands for other types of waste that may be considered hazardous waste. There is no recycling of any kind of municipal waste. The municipal landfill was closed in 2012, so now the municipal waste is dis 
posed of at landfills scattered in the environment in the municipalities of Kosovska Mitrovica and Zvecan, which greatly affects the general hygiene of the area and thus does not exclude infection.

\subsubsection{Industrial landfills}

In the territory of the municipality of Kosovska Mitrovica and Zvecan, there are the industrial landfills located along the bed of the river Ibar, and are the products of the plant in RMHK Trepca, which are: flotation landfills Žarkov Potok, Gornje polje and Žitkovac (Figure 4).

The total amount of flotation tailings deposited on industrial landfills in the territory of the municipalities of Kosovska Mitrovica and Zvečan, is given in Table 3.

Table 3 Table of deposited flotation tailing

\begin{tabular}{||l|c|c|}
\hline \multicolumn{1}{|c|}{ Landfill } & Quantity (t) & Volume $\left(\mathbf{m}^{\mathbf{3}}\right)$ \\
\hline $\begin{array}{l}\text { Gornje and Donje polje } \\
\text { Active from 1930 to 1965 }\end{array}$ & $26,344,212$ & $8,498,133$ \\
\hline $\begin{array}{l}\text { Žitkovac } \\
\text { Active from 1965 to 1975 }\end{array}$ & $7,594,932$ & $2,449,979$ \\
\hline $\begin{array}{l}\text { Zarkov potok } \\
\text { Active from 1975 }\end{array}$ & $9,961,113$ & $3,123,262$ \\
\hline Total & $43,900,257$ & $14,071,374$ \\
\hline
\end{tabular}

In order to determine the influence of mentioned industrial landfills on the environment, characterization of the deposited material was performed. This paper presents the results for the landfill Gornje and Donje polje

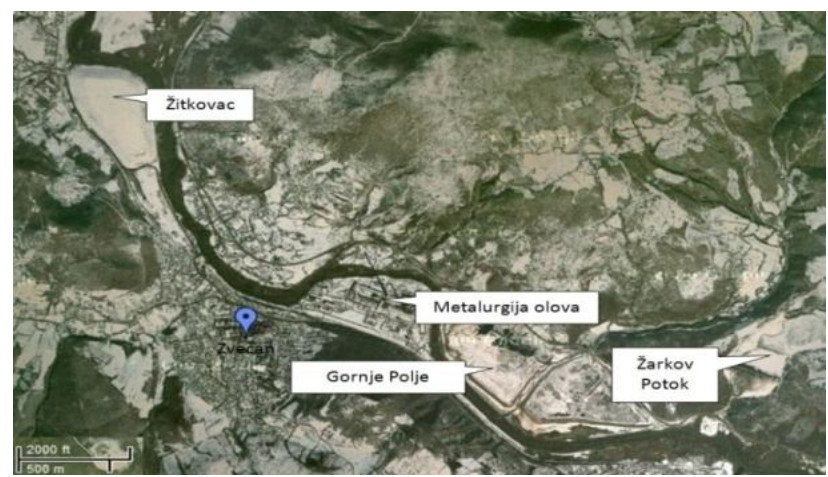

Figure 4 The spatial position of the industrial landfills

\subsection{Characterization of the flotation landfill Gornje and Donje polje}

For the purpose of the detailed characterization of the deposited tailings chemical analysis, scanning electron microscopy, X-ray diffractometry was performed and the particle size distribution was determined.

\subsection{Chemical composition and parti- cle size distribution}

The following table presents the results of chemical analysis of the content of the final flotation tailings of the landfill Gornje and Donje polje. 
Table 4 Tabular presentation the final tailings on the landfill Gornje and Donje polje

\begin{tabular}{|c|c|c|c|c|c|c|c|c|c|c|c|c|c|c|}
\hline $\begin{array}{c}\text { No. of } \\
\text { samples }\end{array}$ & $\mathrm{Pb}$ & $\mathrm{Zn}$ & $\mathrm{Cu}$ & $\mathrm{Fe}$ & $\mathrm{S}$ & $\mathrm{Mn}$ & $\mathrm{Sb}$ & $\mathrm{As}$ & $\mathrm{FeS}_{2}$ & $\mathrm{FeS}$ & $\begin{array}{c}\mathrm{Ag} \\
\mathrm{gr} / \mathrm{t}\end{array}$ & $\mathrm{Pb}_{0 \mathrm{x}}$ & $\mathrm{Z}_{\mathrm{nox}}$ & $\mathrm{Cd}$ \\
\hline I & 0.28 & 0.27 & 0.033 & 27.96 & 17.11 & 5.25 & - & 0.76 & 18.33 & 18.46 & 7 & 0.037 & 0.030 & - \\
\hline II & 0.29 & 0.24 & 0.045 & 29.88 & 17.22 & 5.77 & - & 0.65 & 15.90 & 22.17 & 11 & 0.037 & 0.030 & - \\
\hline III & 0.27 & 0.24 & 0.045 & 23.93 & 12.14 & 6.70 & - & 1.01 & 15.64 & 9.35 & 8 & 0.048 & 0.077 & 0.006 \\
\hline IV & 0.23 & 0.26 & 0.030 & 22.90 & 10.18 & 7.57 & - & 1.01 & 14.05 & 6.57 & 11 & 0.068 & 0.084 & - \\
\hline V & 0.28 & 0.28 & 0.021 & 20.83 & 8.79 & 7.60 & - & 1.23 & 13.21 & 3.95 & 8 & 0.075 & 0.075 & - \\
\hline VI & 0.28 & 0.27 & 0.020 & 20.48 & 9.95 & 7.49 & - & 1.17 & 14.67 & 4.98 & 11 & 0.051 & 0.087 & - \\
\hline VII & 0.26 & 0.23 & 0.029 & 21.56 & 12.97 & 11.71 & - & 1.46 & 20.51 & 4.75 & 5 & 0.048 & 0.045 & - \\
\hline VIII & 0.27 & 0.22 & 0.021 & 20.93 & 11.86 & 6.18 & - & - & 16.54 & 7.63 & 11 & 0.045 & 0.043 & - \\
\hline IX & 0.28 & 0.21 & 0.031 & 20.05 & 9.58 & 6.36 & - & 0.74 & 14.13 & 4.83 & 13 & 0.080 & 0.045 & - \\
\hline X & 0.27 & 0.19 & 0.054 & 26.00 & 13.62 & 5.86 & - & 0.80 & 13.15 & 16.69 & 12 & 0.060 & 0.070 & - \\
\hline XI & 0.13 & 0.28 & 0.048 & 23.72 & 12.36 & 6.33 & - & 0.84 & 14.71 & 11.24 & 7 & 0.052 & 0.030 & - \\
\hline XII & 0.27 & 0.20 & 0.049 & 24.65 & 13.40 & 5.93 & - & 0.89 & 11.04 & 19.03 & 11 & 0.044 & 0.035 & - \\
\hline
\end{tabular}

\subsection{Scanning electronic microscopy}

SEM images of samples of tailings (Figure 5) presented here clearly show

the inhomogeneous nature of the landfill.
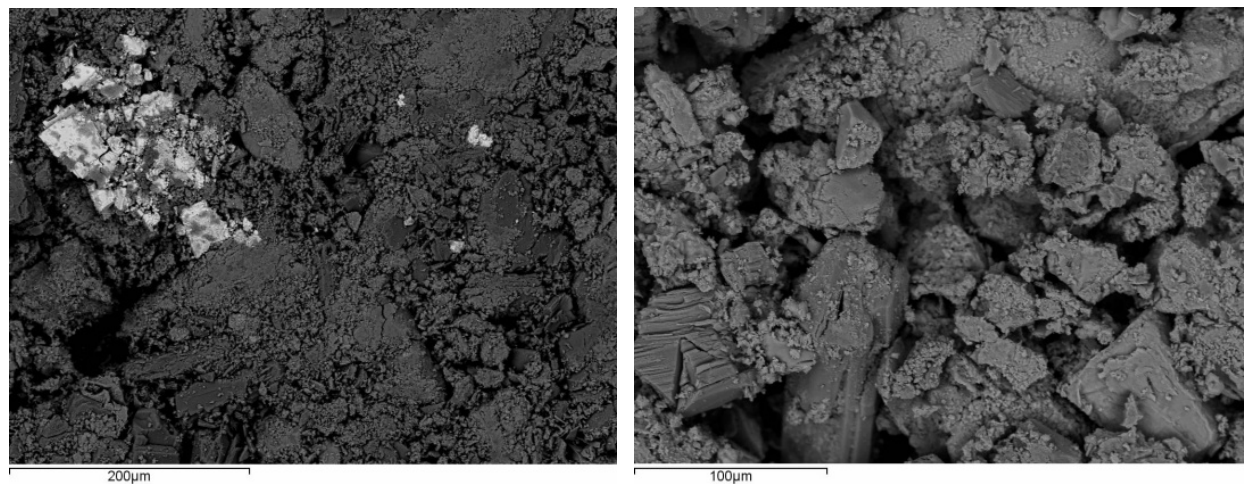

Figure 5 SEM-EDS photos of material from the flotation landfill Gornje and Donje polje at two locations: a) Dudin krš and b) Rudare

From the analysis of samples taken from different periods of ore processing in $\mathrm{RMH}$ Trepca, it can be concluded that with the change of applied technology, the concentration of metals in the tailings is changed. As can be seen in Fig. 5a) taken from the site where the waste was deposited in the first half of the twentieth century, it contained higher amounts of lead, up to $6: 51 \%$ because the technology at that time was ineffective. The glossy points on the SEM images represent particles of lead. The second sample was taken at the location where the tailings were deposited in the period 1950-1983, and then the extraction of metals was better, because modern technology was applied, so that the lead concentration did not exceed $1 \%$, as shown in Figure 5b). [1]

Mineral processing in RMHK Trepca is the process of metal concentrations. The ore is crushed and milled to the average dimension of grain diameter of $0.1 \mathrm{~mm}$, so that the mineral grains open in order to be subjected to flotation reagents. After years of exposure in the open, some of the particles formed aggregates, while the others were reduced under the influence of abrasion, since they were exposed to the wind and precipitation Figure 6. Due to this reason, the analysis of particle size distribution is one of the initial elements for assessment the impact on the environment [1]. The results of particle size 
distribution analysis indicated that the particles can be found scattered in the environ ment, since the landfill Gornje and Donje polje is only partly remediated.

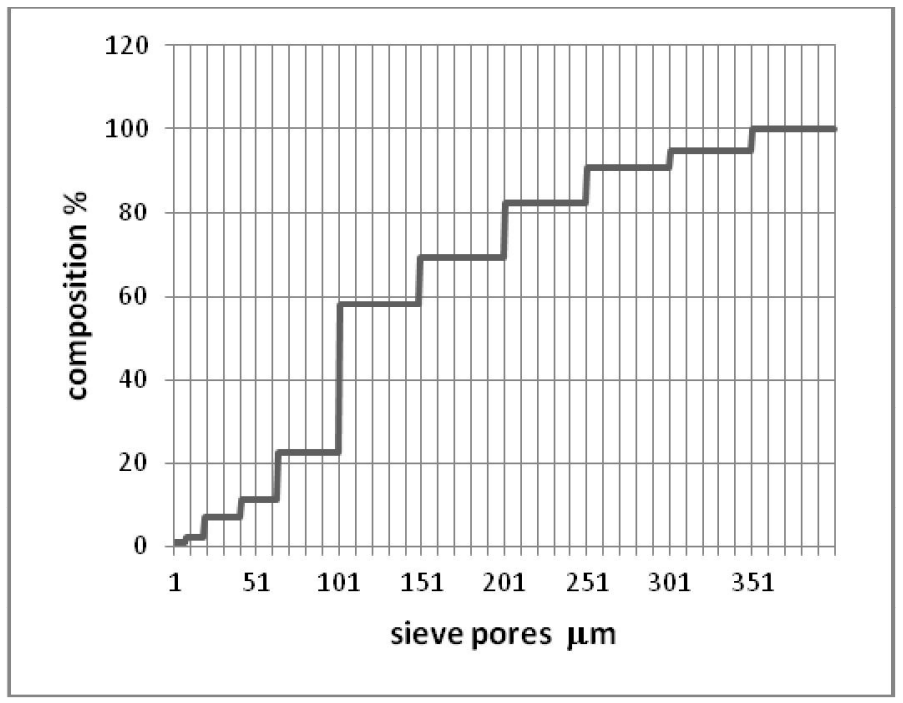

Figure 6 Particle size distribution of flotation tailings [1]

\section{CONCLUSION}

In the territory of the municipality of Kosovska Mitrovica and Zvečan the laws on environmental protection are implemented, with greater or lesser deviations, as follows: the Law on Environmental Protection, Law on Air Protection, Law on Waters, Law on Waste Management and other. In these municipalities, there are no departments for environmental protection. Monitoring the quality of water, air and soil is done according to plans. The monitoring is performed by PHI in Kosovska Mitrovica and CDR, which is a part of Trepca RMHK in Zvecan. The current state of the environment has improved. The reason is the termination of operation of processing facilities of RMHK Trepca. However, the consequences of RMHK Trepca operation for more than 80 years are also now present in almost all media of the environment. The major problems are partially restored, industrial landfills located immediately by the river Ibar bank, near the municipality of Kosovska Mitrovica and Zvecan. Also, a great damage is inflicted by dumps near populated areas, where now, due to the lack of sanitary landfills, the municipal waste is disposed.

\section{REFERENCES}

[1] G. Milentijevic, Ž. Spalevic, Ž. Bjelajac, J. Djokic, B. Nedeljković, Impact Analysis of Mining Company "Trepca" to the Contamination of the River Ibar Water, National Vs. European Law Regulations, Metalurgia international, 18(2013), 283-288;

[2] J. Djokić, D. Minić, G. Milentijević, Z. Kamberović, Stabilization and Solidification of the Tailing Waste Deposit by Using Magnesium Slag, TTEM, 8(2013), 395-405; 
[3] G. Milentijević, B. Nedeljković, I. Ristović, Analysis the Impact of Operation the RMHK Trepca Water Pollution of the River Ibar with Heavy Metals in the Area of Zvecan, III International Symposium ENERGY MINING 2010, Energy Mining, New Technologies, Sustainable Development, 141-147

[4] G. Milentijević, (2005) Groundwater of the Northern Part of Kosovo Metohia - Utilization and Protection,
Belgrade, Faculty of Mining and Geology, 2005, 1-160, PhD thesis, UDK 556.3(497.115)(043.3);

[5] N. Jović, Testing the Soil Samples from the Settlements Rudare, Zvečan and Kosovska Mitrovica and Analysis the Effects on the Environment, Environmental Protection in the Industrial Areas, 2007, Proceedings, 248-254;

[6] Annual Report of ZZJZ Kosovska Mitrovica;

[7] Annual Report of CIR RMHK Trepča. 


\begin{tabular}{ll}
\hline \hline INSTITUT ZA RUDARSTVO I METALURGIJU BOR & ISSN: 2334-8836 (Štampano izdanje) \\
UDK: 622 & ISSN: 2406-1395 (Online) \\
\hline \hline
\end{tabular}

UDK: 504.06:628.515/.516:628.4(045)=163.41

DOI:10.5937/MMEB1404193M

Gordana Milentijević, Blagoje Nedeljković, Jelena Đokić*

\section{SPROVOĐENJE SISTEMA ZAŠTITE ŽIVOTNE SREDINE NA TERITORIJI OPŠTINA KOSOVSKA MITROVICA I ZVEČAN**}

\section{Izvod}

Cilj rada je utvrditi mogućnosti korišćenja sistema zaštite životne sredine RS na teritoriji opština Zvečan i Kosovska Mitrovica. Prikazati rezultate o stanju životne sredine na teritoriji opština Zvečan $i$ Kosovska Mitrovica u period od 2006-2013 g. Uraditi analizu predviđenog zakonskim i podzakonskim aktima ostvarenog u periodu od 2006-2013. g.

Za potrebe ovog rada sakupljane su informacije u službama nadležnih organa koji se bave praćenjem implementacije sistema zaštite životne sredine i praćenjem stanja životne sredine na teritorijama opština Zvečan i Kosovska Mitrovica. Pored toga urađene su analize industrijskih deponija dvema metodama: atomskom apsorpcionom spektroskopijom i skenirajućom elektronskom mikroskopijom.

U opštinama Zvečan i Severna Mitrovica se sprovode zakoni zaštite životne sredine, ali sa manjim ili većim odstupanjima. Za opštinu Kosvska Mitrovica je urađen LEAP, dok su Plan razvoja (2006-2009) $i$ Strategija razvoja (2013-2017) urađene za obe opštine.

Ključne reči: Životna sredina, kvalitet vazduha, Kvalitet vode, Kvalitet zemljišta, industriske deponije, sistemi zaštite životne sredine

\section{UVOD}

Sistem zaštite životne sredine u RS, prema Zakonu o zaštiti životne sredine RS (Sl. Glasnik RS br. 135/2004, 36/2009, 36/2009 - dr. zakon, 72/2009 - dr. zakon i 43/2011 odluka US) čine mere, uslovi i instrumenti za:

1. Održivo upravljanje, očuvanje prirodne ravnoteže, celovitosti, raznovrsnosti i kvaliteta prirodnih vrednosti i uslova za opstanak svih živih bića,

2. Sprečavanje, kontrolu, smanjivanje i sanaciju svih oblika zagađivanja životne sredine.
Ove mere se samo uslovno mogu svrstati u:

1. Administrativne mere zaštite

2. Tehničke mere zaštite

3. Organizacione mere zaštite

4. Ekonomske mere

5. Obrazovanje informisanje

Iz navedenog je proistekao i cilj ovog rada, koji se ogleda u utvrđivanju sprovođenja sistema zaštite životne sredine RS u opštinama Zvečan i Kosovska Mitrovica. $\mathrm{S}$ tim u vezi u radu su prikazani rezultati o stanju životne sredine i analiza predviđena zakonskim i podzakonskim aktima ostva-

\footnotetext{
* Univerzitet u Prištini sa privremenim sedištem u Kosovskoj Mitrovici, Fakultet tehničkih nauka, Kneza Miloša 7,e-mail: blagojenedeljkovic@yahoo.com

** Izvedeno istraživanje je podržano od strane Ministarstva prosvete, nauke i tehnološkog razvoja Republike Srbije (Projekat br. III43007, Projekat br. TR.33045)
} 
renog u periodu od 2006-2013. g u opštinama Zvečan i Kosovska Mitrovica.

Period razvoja privrede od 1918-1941.g., karakteriše obnavljanje rudarstva od strane englesko-srpske kompanije „Trepca mines Limited" po čemu su Zvečan i Kosovska Mitrovica postali prepoznatljivi u svetu.

$\mathrm{Na}$ ovom području se razvijala eksploatacija rude olova i cinka, koncentracija olova i cinka, obojena metalurgija, hemijska industrija i prerađivačka industrija, koja se odvijala u okviru RMHK Trepča. Iz pogona metalurgije cinka dolazilo je do emisije cinka, kadmijuma, fosfora i sumpora u vazduh, vodu i zemljište, a u pogonima metalurgije olova do emisije olova, arsena, antimona, bakra i sumpora. Prenosom kroz životnu sredinu navedenih zagađujućih materija, prouzrokovala su ozbiljna zagađenja teškim metalima u širokoj oblasti koja je obuhvatila doline Ibra i Sitnice. Eksploatacija i koncentracija rude stvarala je velike količine jalovine koja se vremenom akumulirala i prerasla u značajne deponije koje se nalaze blizu naseljenih mesta i na aluvijalnim sedimentima Ibra. Moze se zaključiti da je najveći zagađivač na teritoriji opština Zvečan i Kosovska Mitrovica upravo bio RMHK Trepča, što se i danas odražava na sve segmente životne sredine.

Ovim je definisana problematika koja je izneta u ovom radu, a to su:

1. mogućnosti sporovođenja sistema zaštite životne sredine, $\mathrm{i}$

2. stanje životne sredine na teritoriji opština Zvečan i Kosovska Mitrovica.

\section{EKSPERIMENT}

Za potrebe ovog rada sakupljane su informacije u opštinama Kosovska Mitrovica i Zvečan, u Službama koje se bave praćenjem stanja životne sredine.

U svrhu određivanja uticaja zagađujućih materija iz vazduha, vode i zemljišta na životnu sredinu urađene su analize njihovog kvaliteta.
Takođe, za utvrđivanje uticaja jalovišta na životnu sredinu, pre i posle solidifikacije, izvršena je karakterizacija uzoraka putem hemijskih, fizičkih i mineraloških ispitivanja. Faktor zaprašenja je određen laboratorijski [1].

\subsection{Kontrola kvaliteta vazduha}

Ispitivanje zagađenosti vazduha obuhvata (Centar za istraživanje i razvoj, u daljem tekstu CIR u RMHK Trepča):

1. Ispitivanje taložnih materija i olova pomoću merača i usmerenih merača prašine iz atmosferskih taloga $\mathrm{i}$ padavina

2. Kontrolu gasa $\mathrm{SO}_{2}$ u vazduhu pomoću IMPIDŽER aparata

3. Kontrolu olova u vazduhu pomoću visokoprotočne STAPLEX pumpe u radnoj i urbanoj sredini

Ispitivanja aerozagađenosti obuhvata 24-časovna merenja osnovnih zagađujućih materija $\left(\mathrm{SO}_{2}, \mathrm{NO}_{\mathrm{X}}, \mathrm{i}\right.$ čađi) i mesečna merenja taložnih materija, koja obuhvataju ispitivanje taložnih materija i olova iz atmosferskih taloga i padavina, kontrolu gasa $\mathrm{SO}_{2} \mathrm{u}$ vazduhu i kontrolu olova $\mathrm{u}$ vazduhu (ZZJZ Kosovska Mitrovica).

\subsection{Kontrola kvaliteta vode}

Ispitivanja voda obuhvataju sva ispitivanja vezana za kvalitet pijaćih voda i određivanje koncentracije organskih zagađujućih materija i teških metala u reci Ibru.

Za određivanje metala (katjona) u tečnim uzorcima najčešće se primenjuje atomska apsorpciopna spektrometrija i spektrofotometrija. Pri analizi uzoraka vode reke Ibrar korišćena je metoda AAS.

\subsection{Kontrola kvaliteta zemljišta}

Kontrola kvaliteta zemljišta je vršena u krugu RMHK Trepča i u okolini gde je ispitivan kvalitet obradivog zemljišta. 
Analiza uzoraka okolnog zemljišta rađena je XRF metodom-X-ray Fluorescence (rengerska fluorescencija)

\subsection{Karakterizacija materijala}

Hemijski sastav uzoraka je određen korišćenjem x-Ray fluorescence (ARL86480) uređaja. Ispitivanja skenirajućom electronskom mikroskopijom su rađena na elektronskom mikroskopu Philips XI-300 sa EDXEDAX, sa rezolucijom $1 \mathrm{~nm}(30 \mathrm{kV})$ i $5 \mathrm{~nm}$ $(1 \mathrm{kV})$, naponom od 0.2-30 kV, uvećanjem od 500.000 puta i detektorom za sekundarne i povratne elektrone. Mineraloška ispitivanja su vršena korišćenjem difraktometrijske analize (XRD). Uzorci su ispitivani na difraktometru Philips PW 1710 pod sledećim uslovima: Zračenje iz bakarne entikatode sa $\mathrm{CuK}_{-}=1.54178$ _ I grafitnim monohromatorom radnog napona $U=40 \mathrm{kV}$, jačine struje $I=30 \mathrm{~mA}$. Uzorci su ispitivani u opsegu 2_ 4-90 (sa korakom od $0.02^{\circ} \mathrm{i}$ 0.8 s). Granulometrijski sastav je određen na BSF cikosajzeru [2].

\section{REZULTATI I DISKUSIJA}

\subsection{Administrativne mere u oblasti životne sredine na teritoriji opština Zvečan i Kosovska Mitrovica}

Na teritoriji opština Zvečan i Kosovska Mitrovica sprovode se sledeći zakoni iz oblasti zaštite životne sredine:

1. Zakon o zaštiti životne sredine (Sl. Glasnik RS, br. 135/04),

2. Zakon o zaštiti vazduha (Sl. Glasnik RS, br. 36/09),

3. Zakon o vodama (Sl. Glasnik RS, br. 30/10),

4. Zakon o upravljanju otpadom (Sl. Glasnik br. 36/09)

Ostali zakoni iz oblasti zaštite životne sredine se sprovode sa manjim poteškoćama ili se ne sprovode.

Od strateških dokumenata izrađene su Strategije lokalnog ekonomskog razvoja od 2014-2016. g. Ovi dokumenti predstavljaju uslove da se unaprede ekonomske aktivnosti i životni uslovi područja sa jedne strane, a sa druge strane želje lokalnih samouprava, institucija, ustanova, privrednih subjekata i udruženja da podstiču razvoj svojih opština i da aktivnim učešćem doprinesu njihovom razvoju. Definisane su prioritetne oblasti:

1. Jačanje kapaciteta institucija i ljudskih resursa za lokalni ekonomski razvoj

2. Održivo korišćenje prirodnih reursa $i$ zaštita životne sredine

3. Povlačenje investicija i razvoj malih i srednjih preduzeća

4. Razvoj poljoprivrede i sela

5. Razvoj turizma.

Od planskih dokumenata za opštinu Kosovska Mitrovica odrađen je LEAP.Ovaj dokument predstavlja uslov za dalji održivi razvoj grada, čijom implementacijom se unapređuje stanje životne sredine i zdravlja ljudi.

U LEAP-u su opisani glavni problem u oblasti životne sredine:

1. Velike koncentracije rudarske, obojene metalurgije i proizvodnja hemijske industrije na malom prostoru.

2. Blizina industrijske zone u odnosu na naseljena mesta.

3. Industrijski pogoni RMHK Trepče locirani su u pravcu dominantnih vetrova u odnosu na naseljena mesta

4. Stalna opasnost od mogućih hemijskih udesa kada su proizvodni pogoni RMHK Trepče u proizvodnoj funkciji.

5. Nepoštovanje zakonske regulative iz oblasti zaštite životne sredine.

6. Negativan uticaj NATO bombardovanja 1999.g na životnu sredinu.

\subsection{Organizacione mere u oblasti zaštite životne sredine na teritoriji opština Zvečan i Kosovska Mitrovica}

Opštine Kosovska Mitrovica i Zvešan nemaju u svom sastavu odeljenja za zaštitu životne sredine. Najveći zagađivač životne sredine, u ovim opštinama je RMHK 


\subsubsection{Emisija zagađivača}

Trepča. U Zvečanu se nalazi Metalurgija olova sa Topionicom i Rafinerijom, Fabrika za preradu Aku-otpada, Elektrana i dr.. U ovim pogonima se od koncentrata olova proizvode osim sirovog i rafinisanog olova $\mathrm{i}$ različite vrste olovnih legura, srebro i zlato. Posle 1999. g. RMHK Trepča prestaje sa radom. Sada najveću opasnost u životnoj sredini čine industrijske deponije koje su formirane od otpada koji nastao u pogonima RMHK Trepča.

U opštini Kosovska Mitrovica postoji Fakultet tehničkih nauka na kom se obučavaju kadrovi za oblast zaštite životne sredine, u okviru studijskog programa IZŽS i ZR. U opštini Zvečan nalazi se STŠ u kojoj postoji smer zaštita životne sredine.

U opštini Kosovska Mitrovica je sedište Nevladine organizacije EKOSS (Ekologija spas za sve nas), osnovana 2002. U cilju:

1. Zaštite životne sredine i okoline,

2. Recikliranja otpadnog materijala,

3. Podizanja svesti građana (radionice, seminari, diskusije).

\subsubsection{Kvalitet vazduha}

Praćenje kvaliteta vazduha sprovodi se prema zakonu o zaštiti vazduha objavljenog u (Sl. Gl. RS, br. 36/2009, 15. 05. 2009. g). U ovom zakonu je dato upravljanje kvalitetom vazduha, kao i način kontrole i sprovođenja zaštite i poboljšanja kvaliteta vazduha.

Glavni izvori zagađenja vazduha u Kosovskoj Mitrovici i Zvečanu čine produkti sagorevanja goriva u domaćinstvima, toplanama, individualnim kotlarnicama, zatim saobraćaja, građevinske delatnosti, neodgovarajuće skladištenje sirovina, neodgovarajuće deponovanje industrijskog otpada, smetlište, stepen javne higijene i dr.
Na području Kosovske Mitrovice se ne vrše merenja zagađivača na osnovu Pravilnika o graničnim vrednostima emisije, načinu i rokovima merenja i evidentiranja podataka o izvršenim merenjima. Emisija zagađivača je obrađena samo analiziranjem emisije $\mathrm{SO}_{2}, \mathrm{CO}$ i NO Xiz Toplane na osnovu kvaliteta mazuta i njegove potrošnje.

\subsubsection{Imisija zagađivača}

Srednje mesečne i godišnja vrednost koncentracije $\mathrm{SO}_{2}, \mathrm{NO}_{\mathrm{X}} \mathrm{i}$ čađi je dobijena na osnovu dnevnih merenja. U toku godine se obave 365 merenja. Osim koncentracije $\mathrm{SO}_{2}$, $\mathrm{NO}_{\mathrm{X}}$ i čađi, određuju se i količine toksičnih metala iz svakog uzorka taložnih materijaolova, kadmijuma, nikla, cinka i šestovalentnog hroma.

Iz godišnjaka ZZJZ Kosovska Mitrovica analizirali smo stanje zagađenosti vazduha za 2006. g., 2007. g. i 2008. g., kada nije došlo do prekoračenja $\mathrm{MDK}$ imisije $\mathrm{SO}_{2}$, $\mathrm{NO}_{\mathrm{x}}$, osim za čađ. Srednje mesečne i srednje godišnje koncentracije istaloženih materija ne prelaze MDK za 2006. g., 2007. g. i 2008. g., osim u aprilu mesecu kada su izmerene vrednosti iznosile $632,56 \mathrm{mg} / \mathrm{m}^{2}$ (Merno mesto Elektrodistribucija) i 490,74 $\mathrm{mg} / \mathrm{m}^{2}$ (Dečije obdanište) [6]

Iz rezultata preuzetih iz godišnjeg izveštaja CIR RMHK Trepča za 2008. g. može se zaključiti da je srednja godišnja koncentracija taložnih materija ispod graničnih vrednosti imisije (GVI-300-450 mg/m²/dan). Takođe se može zapaziti da je najveća srednja godišnja koncentracija olova zabeležena na mernom mesto Rudare - gater i iznosi 400,06 $\mu \mathrm{g} / \mathrm{m} / \mathrm{dan}$ (slika 1), što je posledica aktivnosti u nekadašnjem pogonu crepociglane u mestu Žitkovac (sušenje šljake i topljenje olova), kao i obilnih padavina i duvanja jakih vetrova [7] 


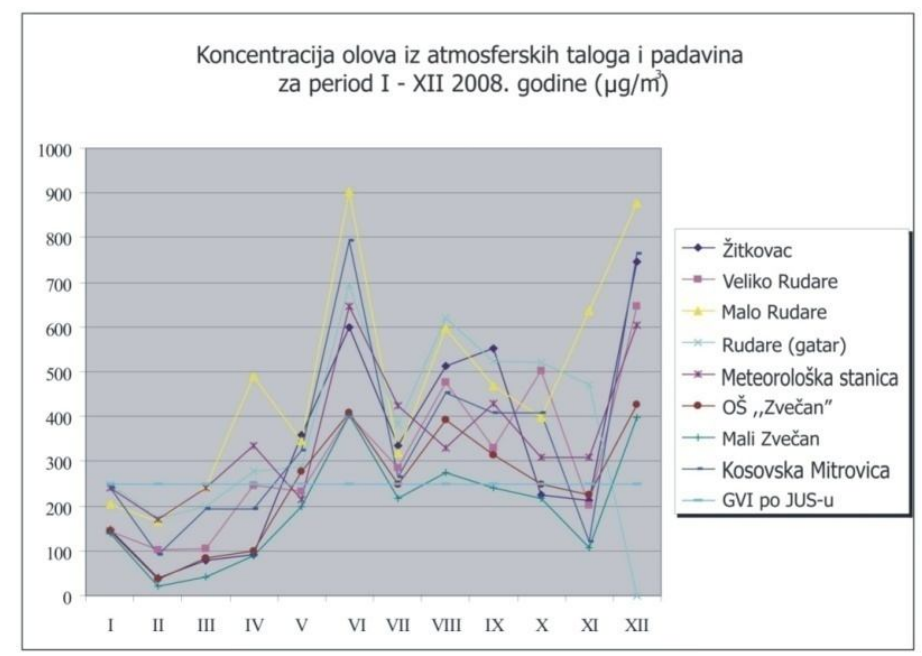

S1. 1. Grafički prikaz koncentracija olova iz atmosferskuh taloga i padavina za period I-XII 2008. $g$ [7]

\subsubsection{Kvalitet vode}

Kvalitet vode sprovodi se prema Zakonu o vodama (Sl. Gl. RS, br. 30/10). Sva ispitivanja vezana za kvalitet atmosferskih i otpadnih voda, koje se ispuštaju u recepijente, vrši ZZJZ u skladu sa zakonskim propisima, a pre svega Zakonom o vodama (Sl. gl. RS, br.46/91, 53/93, 48/94, 54/96), Pravilnikom o opasnim materijama u vodama (Sl.Gl. RS, br. 31/82), Pravilnikom o načinu ispitivanja kvaliteta otpadnih voda (Sl. gl. RS, br. 47/83), Uredbom o kategorizaciji vodotokova (Sl. gl. RS, br. 5/68), Uredbom o klasifikaciji voda (Sl. gl. RS, br. 6/78) kao i odgovarajućim odlukama Skupštine Opštine.

CIR vrši ispitivanja vode koje obuhvataju određivanje teških metala u Ibru.

\subsubsection{Kvalitet pijaćih voda}

U periodu od 2006. g. - 2013. g. ZZJZ godišnje ispituje hemijsku i bakteriološku ispravnost pijaće vode na broju uzoraka koji se kreće u godišnjem opsegu od 3691018 uzoraka u opštinama Kosovska Mitrovica i Zvečan. Od ovog broja vrednosti hemijski neispravnih uzoraka pijaće vode se kreće u opsegu od 2,56 \% - 5,4\% (Kosovska Mitrovica) i od 4,16\% - 3,15\% (Zvečan); srednja vrednost bakteriološki neispravnih uzoraka se kreće u opsegu od 9,58 \% - 11,6 \% (Kosovska Mitrovica) i oko $10,58 \%$ - 14,9\% (Zvečan) [6]

\subsubsection{Rezultati analize prisustva teških metala u reci Ibar}

CIR određuje koncentracije teških metala (Cu (mg/l), Fe (mg/l), Pb (mg/l), Cd (mg/l) i $\mathrm{Zn}(\mathrm{mg} / \mathrm{l}))$ i osnovnih parametara pokazatelja kvaliteta vode: $\mathrm{pH}$, ukupne taložne materije, rastvorene materije, nerastvorene materije, $\mathrm{SO}_{4}$ i $\mathrm{Ca}$ u reci Ibar, jednom mesečno. Merna mesta uzorkovanja vode su tako projektovana da oslikavaju pravo stanje kvaliteta vode reke Ibar na teritoriji opština Kosovska Mitrovica i Zvečan [3].

Značajniji zagađivači na teritoriji opština Kosovske Mitrovice i Zvečana skoncentrisani su uglavnom u slivnom području Ibra, neposredno uz korito reke ili na aluvijalnoj ravni. Neke najosnovnije karakteristike važnijih zagađivača sa mestom izlivanja dati su u Tabeli 1 [3]. 
Tabela 1. Karakteristike važnijih zagađivača na teritoriji opština Kosovska Mitrovica i Zvečan

\begin{tabular}{|c|c|c|c|c|}
\hline $\begin{array}{c}\text { Redni } \\
\text { broj }\end{array}$ & Naziv zagađivača & $\begin{array}{c}\text { Karakteristike } \\
\text { zagađivača }\end{array}$ & Napomena & $\begin{array}{c}\text { Mesto } \\
\text { izlivanja }\end{array}$ \\
\hline 1. & $\begin{array}{c}\text { Flotacijska } \\
\text { deponija } \\
\text { "Žarkov potok" }\end{array}$ & $\begin{array}{c}\text { Kompleksno hemijsko } \\
\text { zagađenje }\end{array}$ & $\begin{array}{c}\text { Povremeno } \\
\text { zagađenje }\end{array}$ & $\begin{array}{c}\text { Žarkov } \\
\text { potok }\end{array}$ \\
\hline 2. & $\begin{array}{c}\text { Deponija } \\
\text { "Gornje polje" }\end{array}$ & $\begin{array}{c}\text { Kompleksno hemijsko } \\
\text { zagađenje }\end{array}$ & Stalno zagađenje & Reka Ibar \\
\hline 3. & Metalurgija Pb & $\begin{array}{c}\text { Zagađenje teškim } \\
\text { metalima }\end{array}$ & $\begin{array}{c}\text { Pogon van } \\
\text { proizvodnje }\end{array}$ & Reka Ibar \\
\hline 4. & $\begin{array}{c}\text { Deponija } \\
\text { "Žitkovac" }\end{array}$ & $\begin{array}{c}\text { Kompleksno hemijsko } \\
\text { zagađenje }\end{array}$ & Stalno zagađenje & Reka Ibar \\
\hline
\end{tabular}

Uvidom u godišnje izveštaje CIR u zadanom periodu analize koncentracije teških metala i osnovinih parametara pokazatelja kvaliteta vode u reci Ibar, na teritoriji opština Kosovska Mitrovica i Zvečan, došli smo do konstatacije da one, u određenom broju, odgovaraju vrednostima datim u Zakonu o vodama Sl. Gl. RS, br. 30/10. Na dijagramu slika 2. dato je merno mesto Grabovac (merno mesto oslikava kvalitet vode reke Ibar na izlazu sa teritorije opština Kosovska Mitrovica i Zvečan) gde se zapaža da su povećani sadržaji za teške metale $\mathrm{Pb}, \mathrm{Cu}$ i Fe [7].

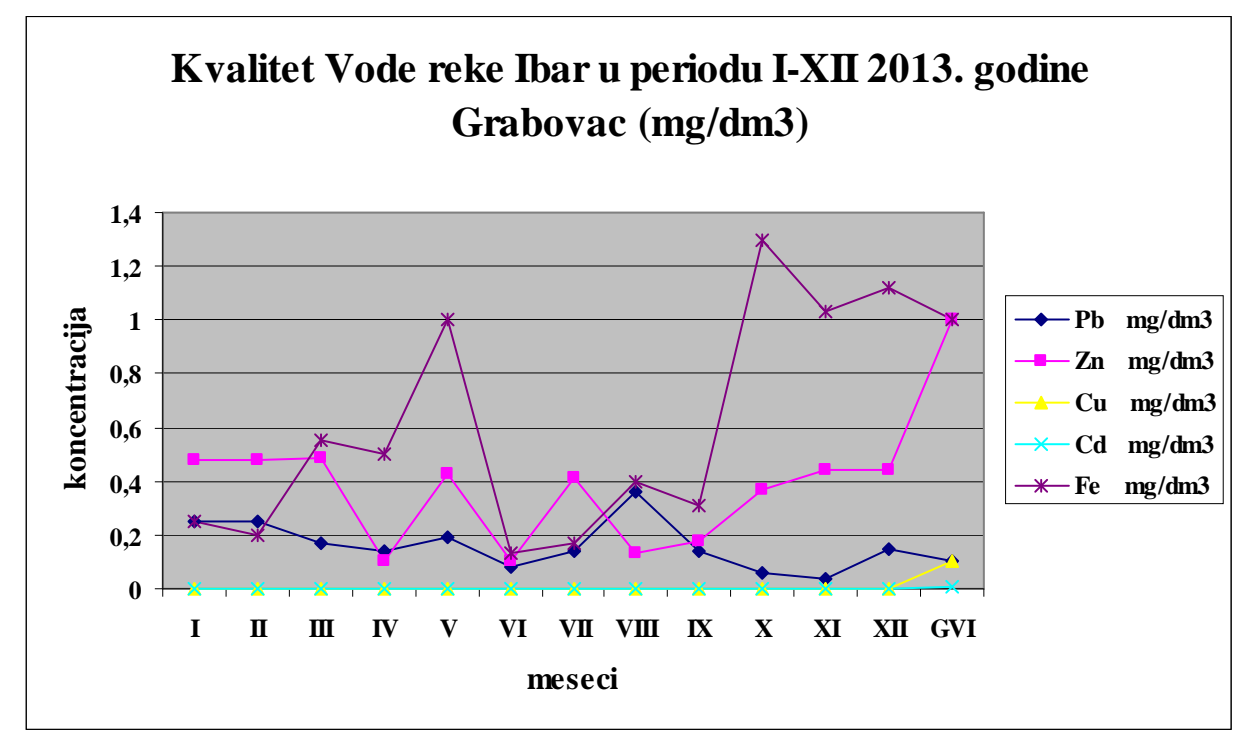

S1. 2. Grafički prikaz koncentracija teških metala [7] 


\subsubsection{Organske zagađujuće materije u reci Ibar na teritoriji opština}

Kosovske Mitrovice i Zvečana

Veliku opasnost od zagađenja organskim materijama predstavljaju termoelektrane Kosova A i Kosovo B u Obiliću. Zbog sagorevanja uglja stalno postoji opasnost da koncentracija fenola u recipijentima bude iznad MDK, što šteti ekosistemima. Takođe, preko vode za piće i hrane ugrožena je i ljudska populacija. Uvidom u godišnje izveštaje ZZJZ Kosovska Mitrovica data je ekcesna situacija kada su analize pokazale prisustvo fenola u vodi reke Ibar.

U Tabeli.2. prikazana je koncentracija isparljivih fenola za prvih šest meseci 2004 god. Ukupno je urađeno 48 uzoraka po standardnoj metodi uz poštovanje procedure konzerviranja uzoraka, destilacije, ekstrakcije, izazivanja boje i merenja apsorbanse. Ova metoda ne daje pravu informaciju o stvarnoj količini fenoinih jedinjenja u vodi, jer je poznato da zagađivač fenolima, Kosovske termoelektrane i površinski ugljenokopi, u svojim otpadnim vodama ne sadrži samo isparljiva već i neisparljiva fenolna jedinjenja [4]. U Tabeli 2. prikazana je koncentracija isparljivih fenola za prvih šest meseci 2004. g.

Tabela 2. Tabelarni prikaz minimalnih, maksimalnih i najčeščih vrednosti koncentracija isparljivih fenola $u$ vodi reke Ibar $(\mu \mathrm{g} / \mathrm{l})$, u prvih šest meseci 2004. g. (Podaci ZZJZ Kosovska Mitrovica, 2004. g )

\begin{tabular}{||l|c|}
\hline Najveća vrednost & $188 \mu \mathrm{g} / \mathrm{l}$ \\
\hline Najmanja vrednost & $1,7 \mu \mathrm{g} / \mathrm{l}$ \\
\hline Najveća vrednost za kišni period & $188 \mu \mathrm{g} / \mathrm{l}$ \\
\hline Najmanja vrednost za kišni period & $14,9 \mu \mathrm{g} / \mathrm{l}$ \\
\hline Srednja vrednost za kišni period & $38,6 \mu \mathrm{g} / \mathrm{l}$ \\
\hline Srednja vrednost za sušni period & $7,5 \mu \mathrm{g} / \mathrm{l}$ \\
\hline Najčešća vrednost za kišni period & $22-58 \mu \mathrm{g} / \mathrm{l}$ \\
\hline Najčešća vrednost za sušni period & $3,7-12,6 \mu \mathrm{g} / 1$ \\
\hline
\end{tabular}

\subsubsection{Kvalitet zemljišta}

Merenje koncentracije teških metala $u$ zemljištu vrši ZZJZ, u skladu sa pravilnikom o dozvoljenim količinama opasnih i štetnih materija u zemljištu i vodi za navodnjavanje i metodama njihovog ispitivanja (Sl. gl. RS, br. 23/94)

Posledice više od 80 godina rada RMHK Trepče i danas utiču na degradaciju zemljišta jer postoji velika količina zagađujućih materija koje su se oslobađale u procesima proizvodnje olova, cinka i hemijske industrije, koje su se deponovale na jalovištima ili su rasuti u životnoj sredini. Mnogobrojne studije su pokazale da je zemljište $u$ darijusu od $10 \mathrm{~km}$ udaljenom od dimnjaka topionice olova u Zvečanu ozbiljno zagađeno uglavnom teškim metalima kao što su olovo, arsen, živa, cink, bakar, nikl i hrom. U ovom radu je dat primer koncentracije arsena i žive na mernim mestima koncentrično raspoređenih oko kruga RMHK Trepča na teritoriji opština Zvečan i Kosovska Mitrovica (slika 3). 
Iz datog dijagrama se vidi da koncentracija arsena prelazi MDK za dozvoljene količine opasnih i štetnih materija koji iznosi do $2 \mathrm{mg} / \mathrm{kg}$ zemlje, dok živa nije izdvojena. Koncentracije ostalih nave- denih teških metala $u$ zemljištu u većini slučajeva prelazile MDK, što je imalo za posledicu i njhovu koncentraciju u biljkama koje se koriste za ljudsku ishranu [5].

Arsen (As), živa (Hg)

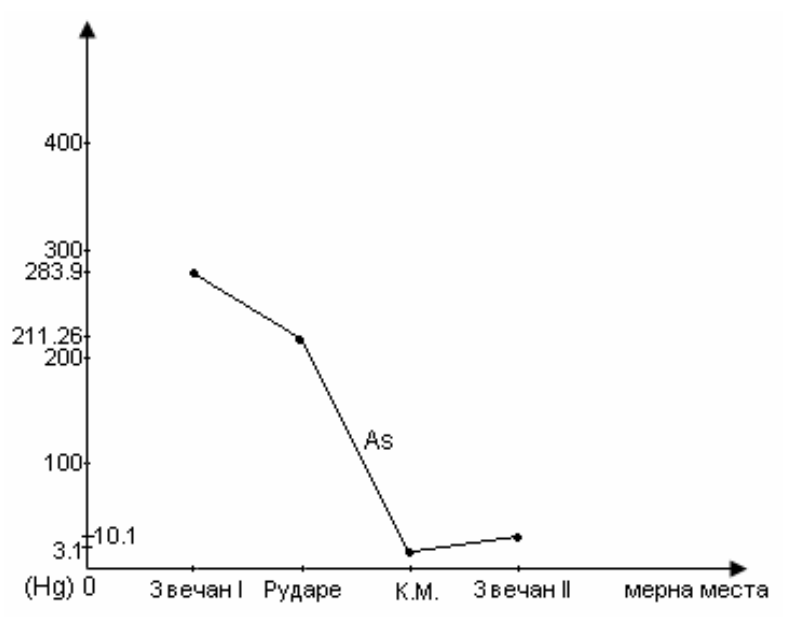

SI. 3. Grafički prikaz koncentracija arsena i žive prema mernim mestima [5]

\subsubsection{Upravljanje otpadom}

Sakupljanje otpada vrši se u skladu sa Zakonom o upravljanju otpadom (Sl. Gl. RS, br. 36/09 i 88/10), kojim se uređuje: vrste i klasifikaciju otpada, planiranje upravljanje otpadom, subjekte upravljanja otpadom, organizovanje upravljanjem otpadom, upravljanjem posebnim tokovima otpadom, uslove i postupak izdavanje dozvola, prekogranično kretanje otpada, izveštavanje o otpadu i bazu podataka, finansiranje upravljanje otpadom, nadzor, kao i druga pitanja od značaja za upravljanje otpadom.

Neadekvatno postupanje sa otpadom predstavlja jedan od najvećih problema $\mathrm{u}$ životnoj sredini na teritoriji opština Kosovska Mitrovica i Zvečan.

\subsubsection{Komunalni otpad}

Sakupljanje, odnošenje i tretman komunalnog otpada je u nadležnosti J.K.P iz
Kosovske Mitrovice i Zvečana. 2002.godine je na teritoriji opštine Zvečan izgrađena deponija Balaban, koja je trebalo da bude regionalnog karaktera za opštine Kosovska Mitrovica, Zvečan, Zubin Potok i Leposavić. Međutim zbog dužine puta i nerentabilnosti opština Zubin Potok ne koristi deponiju.

Izgradnja ove deponije, koja je korišćena zadnjih 10 godina, zadovoljava sve potrebe prilikom odlaganja komunalnog otpada. Sanitarni otpad se ne odvaja jer ne postoji posebna deponija za takav otpad već se iznosi kao komunalni otpad, a to važi i za druge vrste otpada koji se mogu smatrati opasnim otpadom. Ne postoji reciklaža bilo koje vrste komunalnog otpada. Ova komunalna deponija je zatvorena 2012. godine, tako da se sada komunalni otpad odlaže na smetlištima rasejan $\mathrm{u}$ životnoj sredini na teritoriji opština Kosovska Mitrovica i 
Zvečan, što veoma utiče na opštu higijenu o ovoj oblasti, pa ne isključuje i zaraze.

\subsubsection{Industrijske deponije}

Na teritoriji opština Kosovska Mitrovica i Zvečan nalaze se industrijske deponije locirane uz korito reke Ibar, a produkti su rada pogona u RMHK Trepča, to su: flotacijske deponije Žarkov Potok, Gornje polje i Žitkovac (slika 4).

Ukupna količina flotacijske jalovine koja je deponovana na industrijskim deponijama na teritorji opština Kosvska Mitrovica Zvečan data je u Tabeli 3 .

Tabela 3. Tabelarni prikaz deponovane flotacijske jalovine

\begin{tabular}{||l|c|c||}
\hline \multicolumn{1}{|c|}{ Deponija } & Količina (t) & Zapremina $\left(\mathbf{m}^{\mathbf{3}}\right)$ \\
\hline $\begin{array}{l}\text { Gornje i Donje polje } \\
\text { Aktivno 1930. do 1965. g. }\end{array}$ & 26.344 .212 & 8.498 .133 \\
\hline $\begin{array}{l}\text { Žitkovac } \\
\text { Aktivno od 1965. do 1975. g. }\end{array}$ & 7.594 .932 & 2.449 .979 \\
\hline $\begin{array}{l}\text { Žarkov Potok } \\
\text { Aktivno od 1975. g. }\end{array}$ & 9.961 .113 & 3.123 .262 \\
\hline Ukupno & 43.900 .257 & 14.071 .374 \\
\hline
\end{tabular}

U cilju utvrđivanja uticaja navedenih industrijskih deponija na životnu sredinu urađena je karakterizacija deponova- nog materijala. U ovom radu su prikazani rezultati za deponiju Gornje i Donje polje

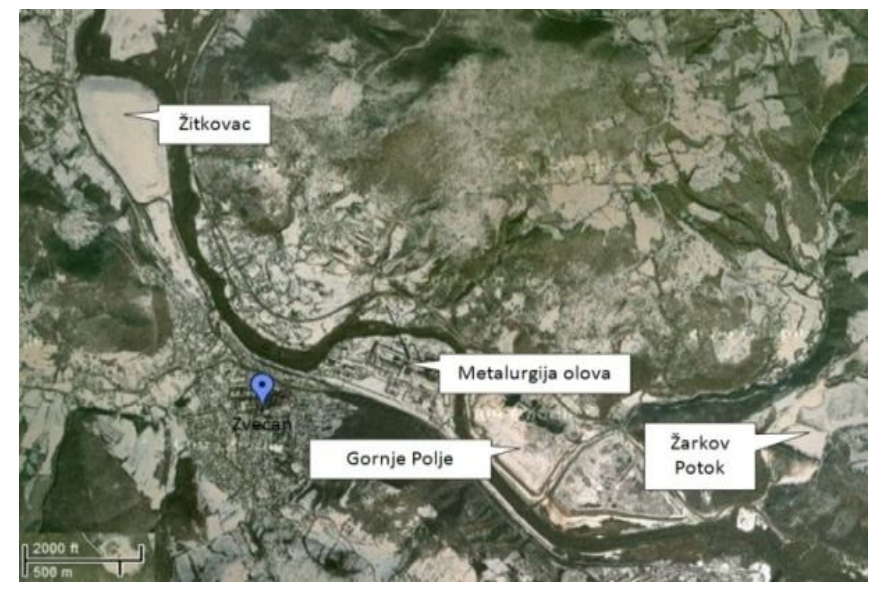

Sl. 4. Prostorni položaj industrijskih deponija

\subsection{Karakterizacija flotacijske deponije Gornje i Donje polje}

U cilju detaljne karakterizacije deponovane jalovine urađene su hemijska analiza, skenirajuća elektronska mikroskopija, rendgenska difraktometrija i određen je granulometrijski sastav.

\subsection{Hemijski i granulometrijski sastav}

U sledećoj tabeli dati su rezultati hemijske analize sadržaja konačne jalovine flotacijske deponije Gornje i Donje polje. 
Tabela 4. Tabelarni prikaz konačne jalovine na deponiji Gornje i Donje polje

\begin{tabular}{|c|c|c|c|c|c|c|c|c|c|c|c|c|c|c|}
\hline $\begin{array}{c}\text { Br. } \\
\text { uzor. }\end{array}$ & $\mathrm{Pb}$ & $\mathrm{Zn}$ & $\mathrm{Cu}$ & $\mathrm{Fe}$ & $\mathrm{S}$ & $\mathrm{Mn}$ & $\mathrm{Sb}$ & $\mathrm{As}$ & $\mathrm{FeS}_{2}$ & $\mathrm{FeS}$ & $\begin{array}{c}\mathrm{Ag} \\
\mathrm{gr} / \mathrm{t}\end{array}$ & $\mathrm{Pb}_{0 \mathrm{x}}$ & $\mathrm{Z}_{\text {nox }}$ & $\mathrm{Cd}$ \\
\hline I & 0,28 & 0,27 & 0,033 & 27,96 & 17,11 & 5,25 & - & 0,76 & 18,33 & 18,46 & 7 & 0,037 & 0,030 & - \\
\hline II & 0,29 & 0,24 & 0,045 & 29,88 & 17,22 & 5,77 & - & 0,65 & 15,90 & 22,17 & 11 & 0,037 & 0,030 & - \\
\hline III & 0,27 & 0,24 & 0,045 & 23,93 & 12,14 & 6,70 & - & 1,01 & 15,64 & 9,35 & 8 & 0,048 & 0,077 & 0,006 \\
\hline IV & 0,23 & 0,26 & 0,030 & 22,90 & 10,18 & 7,57 & - & 1,01 & 14,05 & 6,57 & 11 & 0,068 & 0,084 & - \\
\hline V & 0,28 & 0,28 & 0,021 & 20,83 & 8,79 & 7,60 & - & 1,23 & 13,21 & 3,95 & 8 & 0,075 & 0,075 & - \\
\hline VI & 0,28 & 0,27 & 0,020 & 20,48 & 9,95 & 7,49 & - & 1,17 & 14,67 & 4,98 & 11 & 0,051 & 0,087 & - \\
\hline VII & 0,26 & 0,23 & 0,029 & 21,56 & 12,97 & 11,71 & - & 1,46 & 20,51 & 4,75 & 5 & 0,048 & 0,045 & - \\
\hline VIII & 0,27 & 0,22 & 0,021 & 20,93 & 11,86 & 6,18 & - & - & 16,54 & 7,63 & 11 & 0,045 & 0,043 & - \\
\hline IX & 0,28 & 0,21 & 0,031 & 20,05 & 9,58 & 6,36 & - & 0,74 & 14,13 & 4,83 & 13 & 0,080 & 0,045 & - \\
\hline X & 0,27 & 0,19 & 0,054 & 26,00 & 13,62 & 5,86 & - & 0,80 & 13,15 & 16,69 & 12 & 0,060 & 0,070 & - \\
\hline XI & 0,13 & 0,28 & 0,048 & 23,72 & 12,36 & 6,33 & - & 0,84 & 14,71 & 11,24 & 7 & 0,052 & 0,030 & - \\
\hline XII & 0,27 & 0,20 & 0,049 & 24,65 & 13,40 & 5,93 & - & 0,89 & 11,04 & 19,03 & 11 & 0,044 & 0,035 & - \\
\hline
\end{tabular}

\subsection{Skenirajuća elektronska mikroskopija}

SEM fotografije uzoraka jalovine (slika 5) koje su ovde predstavljene, jasno

pokazuju nehomogenu prirodu ove deponije.
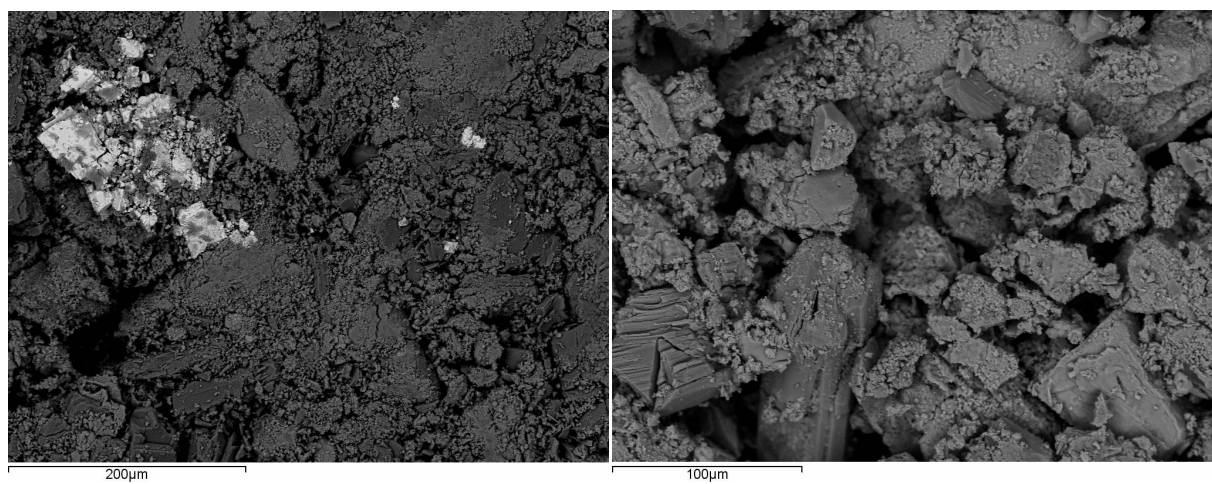

SI. 5. SEM-EDS fotografije materijala sa flotacijske deponije Gornje i Donje Polje na dve lokacije: a) Dudin krš i b) Rudare

Iz analize uzoraka uzetih iz različitih perioda prerade rude u RMH Trepča, može se zaključiti da se sa promenom primenjene tehnologije, menja koncentracija metala $u$ jalovini. Kao što se vidi na Sl. 5.a) uzet sa lokacije gde je deponovan otpad iz prve polovine dvadesetog veka sadrži veće količine olova, čak do $6.51 \%$ zbog toga što je tehnologija u to vreme bila neefikasna. Sjajne tačke na SEM slikama predstavljaju čestice olova. Drugi uzorak je uzet na lokaciji gde se jalovina deponovala $u$ periodu 1950-1983, i tada je ekstrakcija metala bila bolja, jer se primenjivala moderna tehnologija, tako da koncentracija olova nije prelazila $1 \%$, kao što se vidi na sl. 5. b). [1]

Priprema mineralnih sirovina u RMHK Trepča je proces koncentracije metala. Ruda se drobi, a zatim melje na prosečnu dimeniziju prečnika zrna od $0,1 \mathrm{~mm}$, tako da se mineralna zrna otvaraju kako bi bila izložena flotacijskim reagensima. Posle godina izloženosti na otvorenom prostoru, 
neke od čestica su stvorile agregate, a druge su se smanjile pod uticajem abrazije, budući da su bile izložene vetru i padavinama sl. 6 . Iz tog razloga, analiza granulometrijskog sastava je jedan od početnih elemenata za procenu uticaja na životnu sredinu [1]. Rezultati granulometrijske analize ukazuju da se čestice mogu naći rasute u životnoj sredini, budući da deponija Gornje i Donje polje je samo delimično rekultivisana.

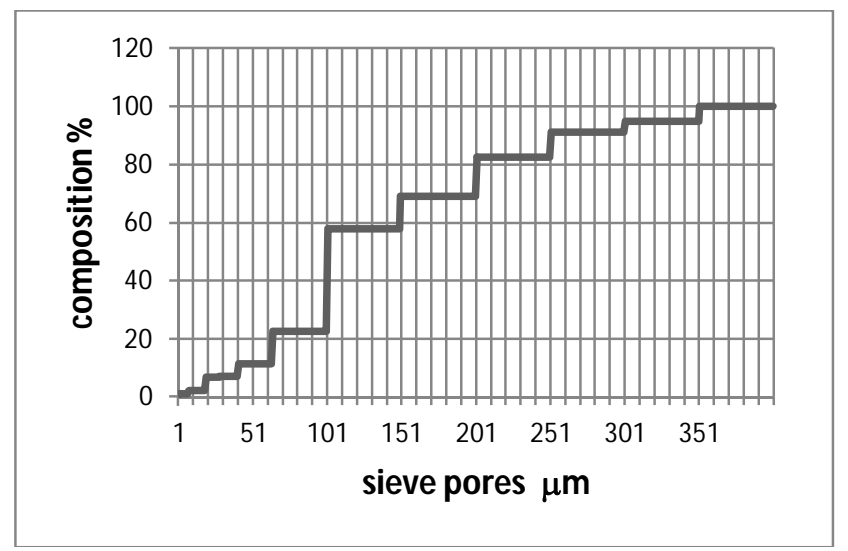

S1. 6. Granulometrijski sastav flotacijske jalovine [1]

\section{ZAKLJUČAK}

Na teritoriji opština Kosovska Mitrovica i Zvečan sprovode se zakoni o zaštiti životne sredine, sa većim ili manjim odstupanjima, i to: Zakon o zaštiti životne sredine, Zakon o zaštiti vazduha, Zakon o vodama, Zakon o upravljanju otpadom i dr. U ovim opštinama ne postoje odeljenja za zaštitu životne sredine. Monitoring kvaliteta vode, vazduha i zemljišta se obavlja planski. Ta praćenja obavljaju ZZJZ u Kosovskoj Mitrovici i CIR koji se nalazi u sastavu RMHK Trepča u Zvečanu. Sadašnje stanje životne sredine se poboljšalo. Razlog je prestanak rada prerađivačkih kapaciteta RMHK Trepča. Međutim posledice rada RMHK Trepča više od 80 godina su i danas prisutne gotovo $u$ svim medijima životne sredine. Veliki problem predstavljaju delimično rekultivisane industrijske deponije koje se nalaze neposredno kraj korita reke Ibar, u neposrednoj blizini opština Kosovska Mitrovica i Zvečan. Takođe veliku štetu nanose smetlišta koja su u blizini naseljenih mesta, gde se sada, zbog nepostojanja sanitarne deponije odlaže komunalno smeće.

\section{LITERATURA}

[1] G. Milentijevic, Ž. Spalevic, Ž. Bjelajac, J. Djokic, B.Nedeljković, Impact Analysis of Mining Company "Trepca" to the Contamination of the River Ibar Water, National Vs. European Law Regulations, Metalurgia international, 18(2013), 283-288

[2] J. Djokić, D. Minić, G. Milentijević, Z. Kamberović, Stabilization and solidification of the tailing waste deposit by using magnesium slag, TTEM, 8(2013), 395-405 
[3] G. Milentijević, B. Nedeljković, I. Ristović, Analiza uticaja rada RMHK Trepča na zagađenje vode reke Ibra teškim metalima na području Zvečana, III Međunarodni simpozijum Energetsko rudarstvo 2010, Energetsko rudarstvo, nove tehnologije, održivi razvoj, 141-147

[4] G. Milentijević, (2005) Podzemne vode severnog dela Kosova i Metohije - iskorišćavanje i zaštita. Beograd: Rudarsko-geološki fakultet, 2005,
1-160, Doktorska disertacija, UDK 556.3(497.115) (043.3)

[5] N. Jović, Ispitivanje uzorka tla iz naselja Rudare, Zvečan i Kosovska Mitrovica i analiza uticaja na životnu sredinu, Zaštita životne sredine u industrijskim područjima 2007. g.- Zbornik radova, 248-254

[6] Godišnji izveštaji ZZJZ Kosovska Mitrovica

[7] Godišnji izveštaji CIR RMHK Trepča 